\title{
Structure elucidation of a flavonoid glycoside from the roots of Clerodendrum serratum (L.) Moon, Lamiaceae
}

\author{
S. S. Bhujbal, ${ }^{* 1}$ R. K. Nanda,1 R. S. Deoda, ${ }^{1}$ Dinesh Kumar, ${ }^{1}$ S. M. Kewatkar, ${ }^{1}$ \\ L. S. More, ${ }^{1}$ M. J. Patil ${ }^{2}$
${ }^{1}$ Department of Pharmacognosy, Pad Dr D. Y. Patil Institute of Pharmaceutical Science and Research, Pune-411018, India,
${ }^{2}$ Marathawada Mitra Mandal's, College of Pharmacy, Pune-411017, India.

\begin{abstract}
RESUMO: Apigenin-7-glucosídeo, $\quad \mathrm{C}_{21} \mathrm{H}_{20} \mathrm{O}_{10}$ (7-( $\beta$-D-glucopiranosiloxi)-5-hidroxi-2(4-hidroxifenil)-4H-1-benzopiran-4-ona), foi isolado pela primeira vez das raízes de Clerodendrum serratum (L.) Moon, Lamiaceae. A elucidação estrutural da susbtância foi feita através de estudos de ${ }^{1} \mathrm{H}$ NMR e FAB-MS.
\end{abstract}

Unitermos:

\begin{abstract}
Apigenin-7-glucoside, $\mathrm{C}_{21} \mathrm{H}_{20} \mathrm{O}_{10}$ (7-( $\beta$-D-glucopyranosyloxy)-5-hydroxy2-(4-hydroxyphenyl)-4H-1-benzopyran-4-one), was first time isolated from the roots of Clerodendrum serratum (L.) Moon, Lamiaceae. Structure elucidation of the compound was carried out by ${ }^{1} \mathrm{H}$ NMR and FAB-MS studies.
\end{abstract}

Keywords: Apigenin, Clerodendrum serratum, FAB-mass spectroscopy.

\section{INTRODUCTION}

Clerodendrum serratum (L.) Moon, Lamiaceae, is a deciduous shrub distributed in the forests of Western Ghats of India (Manjunatha et al., 2004). In Indian system of medicine, the plant is well known as Bharangi (Sanskrit) and commonly known as Blue glory (English). As per the traditional claims roots are potential source of drugs for ailments such as asthma, cholera, and rheumatism (Keshavamurthy, 1994). Phytochemically the root bark extract contain D-mannitol, stigmasterols and three triterpenoids - oleanolic acid, queretaric acid and cerratagenic acid (Banarjee, 1969). This communication reports the structure elucidation of apigenin-7-glucoside (1), a new flavonoid glycoside from the roots of the plant.

\section{MATERIALS AND METHODS}

\section{General}

Melting points were measured on Buchi $545 \mathrm{~B}$, UV Spectra was recorded on Shimadzu 1801, IR spectrum was recorded on Parkin Elmer FT-IR spectrophotometer, FAB-MS was recorded on a Jeol SX 102/Da-600 mass spectrophotometer and ${ }^{~} \mathrm{H}-\mathrm{NMR}$ spectra was recorded on Varian Mercury YH-300 MHz.

\section{Plant material}

Roots of Clerodendrum serratum (L.) Moon, Lamiaceae, were collected from foothills of Sinhagad Pune (India), and authenticated by Botanical Survey of India, Pune with voucher specimen no. SSBC1. A herbarium was also deposited for future reference.

\section{Extraction and isolation}

Roots were shade dried for a week and powdered. Powdered material $(500 \mathrm{~g})$ was extracted using sSoxhlet apparatus with $95 \%$ ethanol for about $36 \mathrm{~h}$. The extract was filtered and concentrated in vacuum under reduced pressure using rotary flash evaporator. A dark brown colored viscous mass weighing $50 \mathrm{~g}(10.0 \% \mathrm{w} / \mathrm{w})$ was obtained. The extract $(10 \mathrm{~g})$ was treated with lead acetate, resulting an yellow precipitate which was then suspended in methanol, treated with hydrogen sulphide to remove the lead and then filtered. After evaporating the filtrate, the residue was treated with boiling water and extracted with ether. The concentrated ether fraction was extracted with sodium hydrogen carbonate solution and acidified with hydrochloric acid. Recrystallization from alcoholwater resulted a yellowish brown amorphous solid (30 $\mathrm{mg}$ ) which was further subjected to spectral analysis. 


\section{RESULTS}

Apigenin-7-glucoside (1) was obtained as yellowish brown amorphous solid having the melting point $178-180^{\circ} \mathrm{C}$. The compound also gave positive color reactions for a hydroxyl flavone with several reagents (Kaneta, 1971). Spectral data for apigenin-7-glucoside as UV-Vis: (ethanol) $\lambda_{\max }$; 247,352 . FT-IR: $(\mathrm{KBR})\left(\mathrm{cm}^{-1}\right)$; 3402, 2920, 2850, 1631, 597. 'H-NMR (300 MHz, TMS, DMSO d $\left._{6}\right): \delta(\mathrm{ppm}) ; 3.5$ (t, $\left.J=3.6, \mathrm{H}-3, \mathrm{CH}\right), 3.8(\mathrm{t}, J=1.8$, $2-\mathrm{H}, \mathrm{CH}_{2} \mathrm{OH}$ ), 4.0 (q, $J=31.5,1-\mathrm{H}, \mathrm{CH}-\mathrm{O}$ ), 4.7 (t, $J=19.5$, $1-\mathrm{H}, \mathrm{CH}_{2} \mathrm{OH}$ ), 4.9 (d, $\left.J=22.5,3-\mathrm{H}, \mathrm{OH}\right), 6.0$ (d, $J=18.3$, 1-H, CH-O), 6.7 (s, 3-H, Ar C-H), 7.1 (d, $J=6.9$ 4-H, Ar $\mathrm{C}-\mathrm{H}), 8.5$ (s, 2-H, Ar-OH). FAB-MS: $m / z ; 433[\mathrm{M}+\mathrm{H}]^{+}$, 432[M+], 271(glucose residue). Molecular formula: $\mathrm{C}_{21} \mathrm{H}_{20} \mathrm{O}_{10}$; Cal. C-58.282\%, H- $4.662 \%$ found; C-58.10\%, $\mathrm{H}-4.59 \%$. From these spectral studies the compound isolated thus confirms of apigenin-7-glucoside.<smiles>O=C1CC(c2ccc(O)cc2)Oc2cc(C[C@@H]3O[C@H](CO)[C@@H](O)[C@H](O)[C@H]3O)cc(O)c21</smiles>

\section{DISCUSSION}

Flavonoids are benzo-pyrone derivatives, which resemble coumarin and are ubiquitous in photosynthesing cells. Their occurrence is therefore widespread in the plant kingdom and about 500 varieties of flavonoids are known (Hausteen, 1983). Previous studies suggests that apigenin-7-glucoside (1) has demonstrated antiinflammatory (Fuchs \& Milbradt, 1993), antimicrobial (Pereira et al., 2007), hepatoprotective (Barbenko \& Shakhova, 2003) and antidiarrheal properties (Meite et al., 2009). The compound also showed significant protection against Alzheimer's disease in mice (Patil et al., 2003). The above literature review describes its importance and therapeutic significance. This communication highlights a new potential source of its occurrence in the roots of Clerodendrum serratum (L.) Moon, Lamiaceae that are widely available throughout the western ghats of India and also explores an opportunity for further research on the biological activity of this group of compounds. As a result, the chances of discovering new plant constituents that may be biologically active are promising.

\section{ACKNOWLEDGEMENTS}

Authors thank the Director and Principal, Pad. Dr. D. Y. Patil Institute of Pharmaceutical Sciences and Research, Pune (India) for providing excellent facilities to carry out the research work. Thanks are also due to Dept. of SAIF, Lucknow and Dept. of SATC, University of Pune, Pune, for their support during spectral analysis.

\section{REFERENCES}

Banarjee SK, Chakravarti RN, Sachdev KS, Vasudev VA 1969. Constituents of root bark of Clerodendrum serratum. Phytochem 8: 515-518.

Babenko NA, Shakhonp EG 2008. Effects of flavonoids on sphingolipid turnover in the toxin-damaged liver and liver cells. Lipids Health Dis 7: 1-11.

Fuchs J, Milbradt R 1993. Skin anti-inflammatory activity of apigenin-7-glucoside in rats. Arzneimittelforschung 3: 370-372.

Havsteen B 1983. Flavonoid, a class of natural products of high pharmacological potency. Biochem Pharmacol 32: 1141-1148

Kaneta M 1971. The constituents of Anthraxon hispidus Makino. Fukushima Tech Jr Col Bull 7: 40-44.

Keshavamurthy KR 1994. Medicinal plants of Karnataka. Karnataka Forest Department, Banglore, India.

Manjunatha BK, Krishna V, Pullaiah T 2004. Flora of Davangere District, Karnataka, India. Regency Publications, New Delhi, India.

Meite S, Guessan JDN, Bahi C, Yapi HF, Diaman AJ, Guina FG 2009. Antidiarrhoeal activity of ethyl acetate extract of Morinda morindoides in rats. Tropical J Pharm Res 3: 201-207.

Patil CS, Singh V, Satyanarayan PSV, Jain NK, Singh A, Kulkarni SK 2003. Protective effect of flavonoids against ageing \& lipopolysaccharide induced cognitive impairment in mice. Pharmacology 69: 59-67.

Pereira AP, Ferreira IC, Marcellino F, Valentao P, Andrade PB, Seabra R, Estevinho L, Bento A, Pereira AJ 2007. Phenolic compounds and antimicrobial activity of olive (Olea europea L. V. Cobrancosa) leaves. Molecules 12: 1153-1162. 